\title{
A felvidéki ${ }^{1}$ és kárpátaljai falusi turizmus összehasonlító jellemzése
}

\author{
SASS ENIKŐ ${ }^{2}$
}

\begin{abstract}
ABSZTRAKT
Egy rövid történelmi bemutatást követően a cikk a szlovákiai (Felvidék) és ukrajnai (Kárpátalja) magyarlakta területek falusi turizmusának fejlódésére és annak perspektíváira összpontosít. A kutatás több szakaszban valósult meg: 1) a témával kapcsolatos szakirodalom áttekintése; 2) a falusi vendégfogadók felkutatása; 3) a falusi turizmussal kapcsolatos vendégfogadói kör felmérésére szolgáló kérdőív összeállítása, kitöltetése Kárpátalján és Felvidéken; 4) az adatok feldolgozása, kiértékelése.

Az empirikus kutatás fö célja volt összehasonlítani a felvidéki kérdöíves felmérés eredményeit a kárpátaljai adatokkal, melyek alapján kimutathatjuk a térben és a különbözó államok hatásai alatt fejlődött területek falusi turizmusában rejlő hasonlóságokat és különbségeket.
\end{abstract}

KULCSSZAVAK: Kárpátalja, Felvidék, falusi turizmus, vendéglátók, vendégházak

\section{ABSTRACT}

\section{A Comparative Study on the Characteristics of Rural Tourism in Transcarpathia and in the Highland}

The article, after a short historical presentation of those Slovakian (the Highland) and Ukrainian (Transcarpathia) regions where Hungarians still play a major role in the population, focuses on the perspectives of rural tourism development in the mentioned areas. The research was conducted in more phases: 1) review of the relevant literature; 2) searching for the eligible hosts; 3) evaluation of the questionnaires distributed among the hosts involved in rural tourism in Transcarpathia and in the Highland; 4) processing and evaluation of data.

The main aim of this empirical research was to compare the Highland questionnaire survey findings with the Transcarpathian data to identify the similarities and differences in rural tourism of these areas that have been developing at different pace and under different socioeconomic conditions in the two countries.

KEYWORDS: Transcarpathia, Highland, rural tourism, hosts, guest houses

\footnotetext{
${ }^{1}$ A vizsgálat szlovákiai része a Visegrádi Alap V4EaP Scholarship programjának 51500923. számú pályázata támogatásával készült.

${ }^{2}$ II. Rákóczi Ferenc Kárpátaljai Magyar Főiskola Földtudományi és Turizmus Tanszék, adjunktus.
} 


\section{TEMATIKUS TANULMÁNYOK - Kárpátalja társadalma}

\section{Bevezetés}

A trianoni békeszerződés után a Magyarországról leszakított területek (Erdély, Kárpátalja, Felvidék, Vajdaság, Muravidék, Horvátország és Őrvidék) különböző országok fennhatósága alá kerültek. Jelen kutatás Kárpátalját és Felvidéket helyezi górcső alá. A történelem folyamán e két terület sorsának alakulása sok hasonlóságot mutat: mindkét terület 1920-tól Csehszlovákia, 1938/39-től Magyarország, 1945-től a Szovjetunió, illetve Csehszlovákia, majd ezt követően Kárpátalja 1991-től Ukrajna, míg Felvidék 1992-tôl Szlovákia fennhatósága alá került.

A történelem során bármelyik országhoz is tartoztak, a természeti szépségekben, ásványi kincsekben, illetve a magyar építészeti és kulturális örökségben is bővelkedő Kárpátalja és Felvidék mindig az adott ország perifériáján helyezkedtek el. Sem a Trianon előtti Magyarország, sem a két világháború közötti Csehszlovákia, sem a Szovjetunió, sem pedig Ukrajna és Szlovákia nem tartotta stratégiai fontosságúnak a térségek teljes körű gazdasági fejlesztését, megerősödését.

A rendszerváltást és a határok könnyebb átjárhatóságát követően főként Magyarország irányából megnőtt az elcsatolt területek iránti megismerési vágy. A turizmus megélénkülése gazdasági lehetőséget hozott az ott élő magyar lakosság számára is. A kutatás folyamán arra kerestem a választ, hogy a többségében vidéki területeken élő szlovákiai és ukrajnai magyar kisebbség (Lanstyák 2000, URL 8 2017, Molnár Molnár D. 2005) életében milyen szerepet játszik a falusi turizmus.

\section{A szakirodalom rövid áttekintése}

\subsection{A FALUSI TURIZMUS FOGALMA}

A falusi turizmus fogalmát a szakirodalom több irányból közelíti meg, de többnyire a nem kiemelt gyógy- és üdülőhelyeken, hanem a falusi és tanyai térségekben folytatott vendégfogadást értjük alatta, amely általában a vendéggel azonos épületben (tanyán) való együttlakás (együttélés) mellett valósul meg, és magába foglalja a vendég részére rendszeresen nyújtott étkeztetés szolgáltatásait is (Magyar Szállodaszövetség 2004). A falusi turizmus a turizmusnak olyan formája, mely a legkisebb jövedelmű rétegek számára is elérhető, s különösen kedvelt a családok és a nyugdíjasok körében (Bodnár 2005).

A szerzők a vidék természeti és kulturális értékeinek (népi építészet, népművészet, tradíciók stb.) bemutatásától a helyi termékek eladásáig, a falusi térségek fejlesztéséig, a helyi közösség megerősítéséig, valamint népességmegtartó hatásáig többféle kedvező vonását emelik ki (Szabó 2000, Kovács 2003, Bodnár 2005). 


\section{TEMATIKUS TANULMÁNYOK - Kárpátalja társadalma}

\subsection{A FALUSI TURIZMUS FOGALMA, MÜKÖDÉSE A KÉT KUTATÁSI TERÜLETEN}

\subsubsection{Kárpátalja falusi turizmusa}

Kárpátalján a falusi turizmus elnevezés a jövedelemkiegészítő vidéki vendégfogadást, vagyis magánházaknál történő szállásadást és a vendégfogadó által kínált étkeztetést, az esetek többségében idegenvezetést, valamint ritkábban programok szervezését jelenti, amelynek alapjait többek között a magyar történelem számos, a területhez köthető emléke, a nyelvi korlátok hiánya, a természeti és kulturális értékek, és nem utolsó sorban Magyarország közelsége teremtette meg (Szilágyi et al. 2006, Sass et al. 2007, Berghauer 2009).

A falusi turizmus a rendszerváltás utáni nehéz gazdasági években élénkült meg Kárpátalján. A bizonytalan gazdasági időszakban sokan, eleinte főként a pedagógusok, felismerték a falusi vendéglátásban rejlő lehetőségeket, és lassan kezdett elterjedni újra ${ }^{3}$ Kárpátalja vidéki területein, különösen a magyarlakta régiókban a falusi vendégfogadás jövedelemkiegészítő ágazata. Mindehhez Kárpátalja értékes természeti és kulturális vonzerői nagyon jó alapot biztosítottak.

A falusi turizmus kárpátaljai sajátosságának tekintendő, hogy szinte minden falusi turizmussal foglalkozó magyar településen van egy (vagy akár több) turizmuszszervező (Sass 2012), aki irányítja a helyi vendégfogadókat és intézi a csoportosan érkező turistákkal kapcsolatos szervezési feladatokat. Napjainkban a legtöbb településen a vendégfogadók létrehozták saját civil szervezetüket, melyekkel tudják biztosítani részvételüket különböző, elsősorban a magyar kormány által biztosított pályázatokon. A helyi szervezetek többsége egy járási szintű ernyőszervezetben, a Beregszász és Térsége Falusi Turizmus Szövetségében tömörül. 2014-ben megalakult a Kárpátaljai Magyar Turisztikai Tanács, mely igyekszik összefogni mindazon magyar turisztikai szervezeteket, egyesületeket, akik részt vesznek Kárpátalja turisztikai arculatának alakításában. Ennek megfelelően a következő munkacsoportokat hozták létre: falusi turizmus, gasztronómia, épített örökség, aktív turizmus, idegenvezetői, borturizmus és fesztiválok. A szervezet célja a közös piaci fellépés, közös programok szervezése, közös érdekképviselet és a szakmai segítségnyújtás.

Kárpátalján a falusi turizmus egy igazi alulról építkező, civil egyesüléseken alapuló szerveződés. Az emberek felismerték a keresleti igényt és ennek megfelelően alakították a kínálatukat. Annak ellenére, hogy az 1991-ben alakult Ukrajna területén belül, mára már több, mint 20 éve múködik a falusi turizmus, az állam nem sokat tett annak támogatása, ösztönzése érdekében, mint ahogy az más országokban történik. Olyannyira nem érzi az állam fontosnak a turizmusnak ezt az ágazatát, hogy

${ }^{3}$ Kaffka Károly (1939) által szerkesztett Az Utas Könyve II. kiegészítő füzet több olyan információt is tartalmaz, mely megerősíti, hogy a Magyarországhoz visszacsatolt Kárpátalján már az I. világháború utáni években is a lakosság foglalkozott magánszállások kiadásával. 


\section{TEMATIKUS TANULMÁNYOK - Kárpátalja társadalma}

a 2003-ban előkészített „A falusi zöld turizmusról” szóló törvénytervezetet (URL 4 2016) Ukrajna Legfelsőbb Tanácsa 2004-ben első olvasatra bár elfogadta, de a mai napig nem léptette jogerőre. Ennek köszönhetően a falusi turizmust Ukrajnában az ország Alkotmánya, „A turizmusról” elfogadott törvény, „A privát parasztgazdaságról" szóló törvény, és Ukrajna más törvényei, rendeletei és határozatai szabályozzák (Izsák 2016). Ez egyáltalán nem segíti a falusi turizmus fejlődését az országban, hiszen nem egyértelműen, egy konkrét törvény alapján történik a falusi turizmus szabályozása. Előrelépést jelent viszont, hogy „A privát parasztgazdaságról” szóló törvényt módosító, a falusi zöld turizmus (Ukrajnában többnyire így nevezik a falusi turizmust) fejlesztését célzó törvénytervezetet fogadott el szintén első olvasatban Ukrajna Legfelső Tanácsa 2017. május 23-i ülésén. Ezek szerint falusi zöld turizmusnak minősül a falusi magángazdálkodás keretében, az adott magángazdaság vagyontárgyainak felhasználásával, a helyi szokásoknak és a vendéglátás hagyományainak megfelelő, egyidejúleg legfeljebb 10 személynek nyújtott, a szállást és étkezést, valamint a szabadidő eltöltésének megszervezését magába foglaló szolgáltatás. A módosító indítvány rögzíti még a végrehajtó hatalom és az önkormányzati szervek kötelezettségeit a falusi magángazdaságok tagjainak a falusi zöld turizmus keretében végzendő tevékenységre való szakmai felkészítése terén (URL3, 2017). Azt egyelőre nem lehet tudni, hogy a törvénytervezetet ilyen formában elfogadják-e és jogerőre léptetik, vagy ez is a falusi turizmus törvényes keretek közé terelésének egy újabb kútba esett próbálkozása lesz.

Ukrajna falusi turizmusának bizonytalan törvényi háttere miatt annak minőségbiztosítási, osztályozási rendszere is kérdéses. Szükségességét minden falusi turizmussal foglalkozó szervezet, szakember fontosnak, időszerűnek, sőt sürgetőnek tartja. Ukrajna függetlenné válása óta volt is néhány kezdeményezés a vendégházak osztályozására, minősítő védjeggyel való ellátására. 1996-ban megalakult a Falusi Zöld Turizmus Fejlődésének Elősegítése Ukrajnában Civil Szervezet, amely 2017-es adatok szerint 20 megyében megközelítőleg 1000 vendégházat fog össze, s körülbelül 15000 vendég fogadására van kapacitásuk (URL 10, 2018). A közvetlen környezet megóvása és a szolgáltatások minőségének javítása céljával 2004-ben a „Független Ökológiai Biztonsági Szolgálat" Tudományos-Természetvédelmi Civil Központtal közösen létrehozták a „Zöld vendégház” ökológiai tanúsítvány programot (1. ábra). 2008-ban pedig bevezetésre kerül a szálláshelyek kategorizációja „Ukrán vendégház" néven (2. ábra) (Кудла 2015). Megalakították a Szakértői-Tanácsadói Intézetet, s 2016. január 1-jéig ${ }^{4}$ az „Ukrán vendégház” program keretében 175 ház 21 megyében, a „Zöld vendégház” program keretében 49 ház 7 megyében lett minősítve (URL 9 2018). Az ország méreteit és a rendelkezésre álló mezőgazdasági és vidéki

${ }^{4}$ Ennél frissebb adatokhoz nem lehetett hozzáférni, mivel a szervezet weboldala (www.greentour. com.ua) jelenleg (2018. január 20.) fejlesztés alatt áll. 


\section{TEMATIKUS TANULMÁNYOK - Kárpátalja társadalma}

területeit tekintve ezek a számok nagyon alacsonynak tekinthetők. Mivel nem állnak rendelkezésre hivatalos statisztikai adatok a falusi és agroturizmust illetően, ezért nem lehet tudni, hogy az országban valóban ilyen kevés azoknak a száma, akik falusi turizmussal foglalkoznak vagy csak egyszerűen nem csatlakoztak a szervezethez és nem foglalkoznak azzal, hogy minősítve legyenek vendégházaik. Egy viszont biztos, ezzel a minősítési rendszerrel Kárpátalja magyarlakta vidékeinek vendégházai nem lettek minősítve. A Kárpátaljai Magyar Turisztikai Tanács ösztönzésére kidolgozás alatt áll a magyarországi napraforgós rendszer adoptálása a kárpátaljai magyar vendégházak minősítése céljából. Mivel az imént bemutatott ukrán minősítési rendszer nem államilag van meghatározva, ezért sikeres próbálkozás lehet a napraforgós rendszer általi minősítési rendszer meghonosítása a magyarlakta vidékeken.

1. ábra. „Zöld vendégház” védjegy

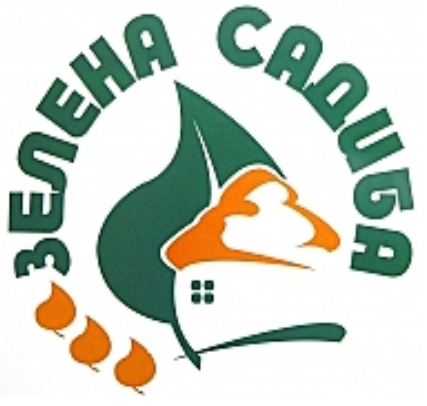

Forrás: URL 92018
2. ábra. Ukrán vendégház" védjegy

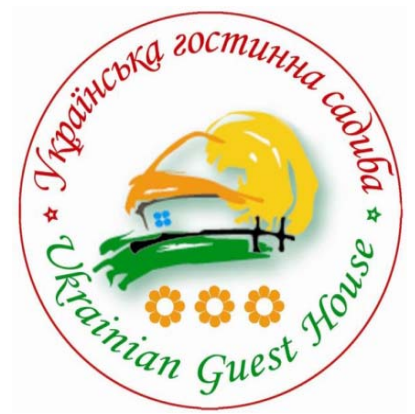

Forrás: URL 102018

\subsection{A FELVIDÉK FALUSI TURIZMUSA}

Szlovákiában a falusi és agroturizmus a szlovák idegenforgalom jelentős speciális ágazata, melyet a Mezőgazdasági Minisztérium támogat a vidék foglalkoztatási lehetőségeinek bővítése és a szlovák természeti és táji erőforrások hasznosítása érdekében (Tardos 1996, idézi Szabó 2009).

Szlovákia falusi és agroturizmusáról több kutatás, tudományos cikk, esettanulmány is megjelent az évek folyamán (Clarke et al. 2001, Chobotova - Kluvankova-Oravska 2006, Otepka - Habán 2007, Habán et al. 2012, Jarábková 2008, 2010). A legtöbb munkában kiemelik a falusi és agrárturizmusban rejlő lehetőségeket, mint például a vidék munkanélküliségének csökkentése, a helyi termékek közvetlen értékesítése, népességmegtartó hatása, a helyi lakosok életszínvonalának növekedése, az elmaradott területek fejlesztése stb. Az egyik kiemelt fontosságú turisztikai ága- 


\section{TEMATIKUS TANULMÁNYOK - Kárpátalja társadalma}

zatnak tartják Szlovákiában, melyet államilag támogatni, fejleszteni és minőségileg javítani kell (URL 3 2016).

Az állami és az uniós támogatások, pályázati lehetőségek ellenére is jóval kevesebb a vidéki turizmus által hasznosított gazdaságok (farmok, tanyák) száma Szlovákiában (kb. 62 (ebből 42 az agroturizmusban)), mint a vele szomszédos országokban (pl. Csehország kb. 355-400) (Habán et al. 2012).

A hivatalos turisztikai statisztikák nem választják szét a falusi és az agroturizmust Szlovákiában. A vidéki területeken különféle szálláslehetőségek állnak a vendégek rendelkezésére (családi házak, parasztházak, kis farmok és nagy panziók), melyek minőségükben és a szolgáltatások színvonalában is különböznek egymástól.

1993 óta müködik a Szlovák Falusi Turizmus és Agrárturizmus Szövetség (Slovak Association for Rural Tourism and Agro-tourism [SARTA], melynek tagjai magánszemélyekből, mezőgazdasági vállalkozókból, farmergazdákból és legális szervezetekből állnak, elkészített egy minőségbiztosító szálláshely minősítést, melyet az agroturisztikai panziók használhatnak (Habán et al. 2012). Szlovákiában az agroturizmus szabályozása a 277/2008 számú (Zbierka zákonov č. 277/2008, URL 5 2016) jogszabályon alapszik, melyben a szálláshely szolgáltatás minőségi szintjét legalább egy és legfeljebb öt csillaggal minősíthetik.

A kutatás és a két terület Felvidék és Kárpátalja falusi turizmusának összehasonlíthatósága szempontjából viszont a nagy agroturisztikai panziók helyett inkább a magánszálláshelyek feltérképezését tartottam fontosnak. A fentebb említett 277/2008 számú jogszabály szerint meghatározásra kerülő magánszállások között, mint például a családi házakban lévő kiadó szobák, vagy erre a célra kialakított egész létesítmény, leginkább családi házak, hétvégi házak, parasztházak, kunyhók, nincs konkrétan nevesítve a falusi szálláshely, a falusi vendégház. A kiadó szobákat, létesítményeket (szlovákul objekt) és lakásokat 1-től 3-ig terjedő csillagokkal minősítik. Azt is meghatározzák, hogy egy szobában a megadott minősítésnek megfelelően hány személyt lehet elszállásolni és milyen felszereléssel kell rendelkezni, de hogy összesen hány személyt lehet ilyen módon fogadni egy „objektumon” belül, az nincs meghatározva.

\section{Célkitűzések, kutatási módszerek}

Az empirikus kutatás fó céljai közé tartoznak:

- bemutatni a két kutatási terület falusi turizmusának fejlettségi szintjét;

- pontos képet kialakítani a magyar kisebbségen belül a falusi turizmussal foglalkozó vendégfogadóinak köréről a szociál-demográfiai adatok vizsgálatán keresztül;

- feltérképezni a vendégházak turistafogadásra való felkészültségét; 


\section{TEMATIKUS TANULMÁNYOK - Kárpátalja társadalma}

- a felvidéki és kárpátaljai kérdőíves felmérés alapján kimutatni a területek falusi turizmusában rejlő hasonlóságait és különbségeit;

- megállapítani, hogy a falusi turizmus kitörési pont volt-e a felvidéki és kárpátaljai magyar kisebbség életében a rendszerváltást követő nehéz években, és mit jelent napjainkban;

- feltárni a két terület erősségeit és gyengeségeit a falusi turizmus tekintetében stb.

A 89 db kárpátaljai és a 26 db felvidéki kérdőív kiértékelését az SPSS és a Microsoft Excel szoftverek segítségével végeztük el. Az adatokat jelen esetben csak esetszám-arányos vizsgálatnak vetettük alá, így hasonlítottuk össze a két kutatóterületet.

\section{A kárpátaljai és felvidéki kutatópontok bemutatása}

A vendégfogadói kör felmérésére szolgáló kérdőívet Kárpátalján 2009-ben, illetve 2011 őszén töltettük ki a Kárpátalján élő tömbmagyarságot magába foglaló és a vidék egyik legjelentősebb falusi vendégforgalmát lebonyolító Beregszászi járás területén.

A Beregszászi járásban 2011-ig 11 településen 135 család foglalkozott szervezett falusi vendégfogadással (Beregdéda, Mezőkaszony, Bene, Mezővári, Mezőgecse, Csetfalva, Nagybakta, Sárosoroszi, Kovászó, Nagyborzsova, Nagymuzsaly). A kérdőíves felmérést ezen települések közül 7 esetében végeztem el, melynek köszönhetően a Beregszászi járás falusi turizmussal foglalkozó települések vendégfogadóinak 66 százalékát mértem fel.

1. táblázat. A kitöltött vendégfogadói kérdőívek száma és megoszlása

Kárpátalján településenként

\begin{tabular}{|l|l|l|c|}
\hline \multicolumn{1}{|c|}{ Megye } & \multicolumn{1}{|c|}{ Járás } & \multicolumn{1}{c|}{ Település } & Kérdőívek száma \\
\hline \multirow{5}{*}{ Kárpátalja } & \multirow{4}{*}{ Beregszászi } & Bene & 17 \\
\cline { 3 - 4 } & & Nagyborzsova & 10 \\
\cline { 3 - 4 } & & Csetfalva & 10 \\
\cline { 3 - 4 } & & Mezőgecse & 11 \\
\cline { 3 - 4 } & & Mezőkaszony & 10 \\
\cline { 3 - 4 } & & Mezővári & 29 \\
\cline { 3 - 4 } & & Nagybakta & 2 \\
\hline Összesen & & & 89 \\
\hline
\end{tabular}

Forrás: Saját szerkesztés 


\section{TEMATIKUS TANULMÁNYOK - Kárpátalja társadalma}

A kárpátaljai vendégfogadókat az internet (URL 6, 2009) és a Beregszász és Térsége Falusi Turizmus Szövetsége segítségével gyűjtöttem össze, s összesen 95 darab kérdőívet töltettem ki, melyből 89 darab felelt meg a kutatás kritériumainak (1. táblázat).

Szlovákia magyarlakta területén (Felvidék) a kutatást 2015-2016 között végeztem el. A szlovákiai magyarság három nagyobb tömbre tagolódik, mely közül a legnagyobb, a Duna menti térség. Ez a volt Pozsony, Komárom, Esztergom, Nyitra és Bars megyék területét öleli fel. A szlovákiai magyar kisebbség közel kétharmadát foglalja magába, ezáltal méltán nevezhető a felvidéki tömbmagyarság területének (Horváth 2004). A szlovákiai kutatást a kárpátaljai felmérés alapján végeztem el főként Dél-Szlovákia magyarok lakta részén (2. táblázat). Habán és szerzőtársai (2012) szerint a falusi turizmussal és agroturizmussal Szlovákiában gyakran foglalkoznak az ország szőlő- és bortermelő vidékein, mint amilyen tulajdonságokkal a választott terület is rendelkezik. Itt található ugyanis a Dél-szlovákiai borvidék, mely az ország második legnagyobb borvidéke.

2. táblázat. A kitöltött vendégfogadói kérdőívek száma és megoszlása

Felvidéken településenként

\begin{tabular}{|l|l|l|c|}
\hline \multicolumn{1}{|c|}{ Kerület } & \multicolumn{1}{|c|}{ Járás } & \multicolumn{1}{|c|}{ Település } & $\begin{array}{c}\text { Kérdőívek } \\
\text { száma }\end{array}$ \\
\hline \multirow{2}{*}{ Nyitrai } & Komáromi & $\begin{array}{l}\text { Bajcs, Búcs (3), Dunamocs (2), } \\
\text { Dunaradvány }\end{array}$ & 7 \\
\cline { 2 - 4 } & Érsekújvári & Ipolyszalka,Helemba, Tótmegyer & 3 \\
\cline { 2 - 4 } & Lévai & Oroszka, Százd & 2 \\
\hline \multirow{2}{*}{ Nagyszombati } & Dunaszerdahelyi & $\begin{array}{l}\text { Alistál (2), Bacsfa, Csallóközkürt, } \\
\text { Egyházkarcsa, Ekecs, Nagyszarva, } \\
\text { Bagyszegmajor, Nemeshódos, Nyárasd, } \\
\text { Nyékvárkony }\end{array}$ & 11 \\
\hline Kassai & Nagykürtösi & Apátújfalu & 1 \\
\cline { 2 - 4 } & Rimaszombati & Újbást & 1 \\
\hline Összesen & Nagymihályi & Nagyráska & 26 \\
\hline
\end{tabular}

Forrás: Saját szerkesztés 


\section{TEMATIKUS TANULMÁNYOK - Kárpátalja társadalma}

Felvidék magyar vendégfogadóinak felkutatása nem volt egyszerű feladat. A kárpátaljai mintához hasonlóan az interneten kezdődött a keresés. Elsődleges forrásként a travelguide.sk (URL 7 2015) honlapot használtam fel. A találatok száma viszont nagyon csekély volt, és egyetlen magyar települést sem találtam, ahol a falusi vendégfogadók „tömegesen” jelentek volna meg hirdetésükkel, mint Kárpátalján. A másik fő problémát az jelentette, hogy bár, a szálláshely jellegénél fel volt tüntetve a „vidéki turizmus”, mégis a legtöbb esetben a szálláshely típusa apartman vagy panzió volt és 20-nál több férőhellyel rendelkezett. A hosszas internetes keresgélés után a nyitrai egyetem turizmus szakos hallgatóinak segítségét is igénybe vettem a lehetséges adatközlők, a falusi vendégfogadók felkutatása során. Ennek eredményeként 42 darab kérdőív lett kitöltve, melyből csak 26 kérdőív felelt meg a kutatás kritériumainak (2. táblázat). A legnagyobb probléma, mely által a 16 darab kérdőív ki lett zárva a feldolgozásból, az a férőhelyek kimagaslóan nagy száma (20-70) volt, mely nem jellemző a tipikus falusi vendéglátásra. A fentebb ismertetett törvény alapján, bár a magánszálláshelyeknél nem volt a férőhelyek száma meghatározva, mégis a kutatás szempontjából szükséges volt korlátot szabni, hogy a kárpátaljai adatokkal összehasonlítható legyen.

\section{Az empirikus kutatás eredményeinek bemutatása}

\subsection{A SZOCIÁLDEMOGRÁFIAI ADATOK BEMUTATÁSA}

A szociáldemográfiai adatok (3. táblázat) szerint a megkérdezett kárpátaljaiak 95,5\% nő és döntően a 40-49 éves korosztály képviselteti magát (41,6\%). Felvidéken hasonló a helyzet, de mind a nemek, mind pedig a korosztály tekintetében lényegesen kisebb a különbség a többi kategóriához képest. A vendégfogadók legtöbbje középfokú végzettséggel rendelkezik mindkét kutatási területen, viszont a felsőfokú végzettséggel rendelkezők aránya kétszer több a Felvidéken (42,3\%), mint Kárpátalján (21,3\%), $\mathrm{s}$ míg az általános iskolai végzettség nem jelenik meg a felvidéki mintában, addig a kárpátaljai vendégfogadók 9\%-a csak ilyen végzettséggel rendelkezik (3. táblázat).

A foglalkozás tekintetében Felvidéken a vállalkozók (61,5\%) dominanciája figyelhető meg, illetve a szellemi alkalmazottak $(19,2 \%)$ aránya kiemelkedő. Kárpátalján viszont a háziasszonyok, háztartásbeliek $(34,8 \%)$ és a szellemi alkalmazottak $(32,6 \%)$ aránya magas, míg a vállalkozók $(5,6 \%)$ aránya csekély. Felvidéken a vállalkozók ilyen magas aránya a falusi vendéglátói tevékenység magánvállalkozói engedélyhez való kötöttségével magyarázható. Kárpátalján is próbálták a falusi turizmust hasonló hivatalos mederbe terelni, de ez mai napig nem valósult meg. Mindkét területen a válaszadók többsége családi állapotuk szerint házas (76,9\% és 92,1\%) és átlagosnak ítélték jövedelmüket (3. táblázat). 
www. metszetek.unideb.hu

\section{TEMATIKUS TANULMÁNYOK - Kárpátalja társadalma}

3. táblázat. A vendégfogadói minta alapadatainak megoszlása.

( $\mathrm{F} \%=$ a felvidéki minta \%-os arányban, $\mathrm{N}=26 ; \mathrm{K} \%=$ a kárpátaljai minta \%-os arányban, $\mathrm{N}=89$ )

\begin{tabular}{|c|c|c|c|}
\hline \multicolumn{2}{|r|}{ Jellemzők } & $F \%$ & $K \%$ \\
\hline \multirow[t]{2}{*}{ Nem } & nő & 57,7 & 95,5 \\
\hline & férfi & 42,3 & 4,5 \\
\hline \multirow[t]{5}{*}{ Életkor } & 20-29év & 0,0 & 7,9 \\
\hline & 30-39 év & 19,2 & 25,8 \\
\hline & 40-49 év & 30,8 & 41,6 \\
\hline & 50-59 év & 26,9 & 21,3 \\
\hline & 60 év felett & 23,1 & 3,4 \\
\hline \multirow[t]{3}{*}{ Végzettség } & általános iskola & 0,0 & 9,0 \\
\hline & középfokú & 57,7 & 69,7 \\
\hline & felsőfokú & 42,3 & 21,3 \\
\hline \multirow[t]{6}{*}{ Családi állapot } & nős/férjezett & 76,9 & 92,1 \\
\hline & nőtlen/hajadon & 0,0 & 1,1 \\
\hline & nős/férjezett de külön élő & 3,8 & 0,0 \\
\hline & özvegy & 7,7 & 6,8 \\
\hline & elvált & 7,7 & 0,0 \\
\hline & élettársi kapcsolatban él & 3,8 & 0,0 \\
\hline \multirow[t]{10}{*}{ Foglalkozás } & nyugdíjas & 7,7 & 11,3 \\
\hline & fizikai alkalmazott & 3,8 & 7,9 \\
\hline & háziasszony, háztartásbeli & 3,8 & 34,8 \\
\hline & jelenleg állás nélkül & 0,0 & 0,0 \\
\hline & szellemi alkalmazott & 19,2 & 32,6 \\
\hline & alkalmi munkás & 0,0 & 0,0 \\
\hline & vállalkozó & 61,5 & 5,6 \\
\hline & családi gazdaságban dolgozó & 0,0 & 3,4 \\
\hline & vezető alkalmazott & 3,8 & 2,2 \\
\hline & a többi 3 kategória összesen & 0,0 & 2,2 \\
\hline \multirow[t]{5}{*}{ Jövedelem } & jelentősen az átlag alatt & 0,0 & 1,1 \\
\hline & valamivel az átlag alatt & 3,8 & 3,4 \\
\hline & átlagos & 46,2 & 80,9 \\
\hline & valamivel az átlag felett & 38,5 & 13,5 \\
\hline & \begin{tabular}{|l|} 
jóval az átlag felett \\
\end{tabular} & 11,5 & 1,1 \\
\hline
\end{tabular}

Forrás: Saját szerkesztés 


\section{TEMATIKUS TANULMÁNYOK - Kárpátalja társadalma}

A 89 kárpátaljai vendégfogadó 87,6\%-a és a 26 felvidéki vendégfogadó 88,5\%-a bevallása szerint beszél valamilyen idegen nyelvet. Magyar anyanyelvűként az államnyelvet mindkét országban idegen nyelvnek tekintik a válaszadók. A kárpátaljaiak főként oroszul $(74,4 \%)$ és ukránul $(71,8 \%)$ beszélnek, s 10\%-nál kevesebben beszélnek valamilyen másik idegen nyelvet (angol, német stb.). A felvidéki válaszadók 60,9\%-a beszél szlovákul, 30,4\%-a pedig cseh nyelven. Viszont jóval nagyobb az egyéb idegen nyelvet beszélők aránya: angol 56,5\%, német 39,1\%, orosz $21,7 \%$, lengyel 13,0\% stb. A nyelvtudás szintjénél szembetűnő, hogy az ukrán nyelven beszélő kárpátaljai magyarok csupán 12,5\%-a beszéli felsőfokon az ukrán nyelvet, addig a szlovákul beszélő felvidékiek 85,7\%-a beszél felsőfokon szlovákul.

\subsection{A VENDÉGHÁZAK ÉS A SZOLGÁLTATÁSOK JELLEMZÉSE}

Falusi vendéglátással mindkét területen átlagosan 10 éve foglalkoznak a megkérdezett vendégfogadók. Felvidéken a vendéglátók többsége kulcsos házban $(60,0 \%)$, Kárpátalján pedig inkább saját lakóházában kialakított, külön bejáratú szobákban fogadja a vendégeket (62,9\%). Felvidéken a második helyen áll, de arányaiban jóval lemaradva, a lakóház udvarához tartozó különálló épület (16,0\%), illetve Kárpátalján a lakóházhoz tartozó külön bejáratú lakrész (20,2\%) (3. ábra).

3. ábra. Hol fogadja a vendégeket? (\%)

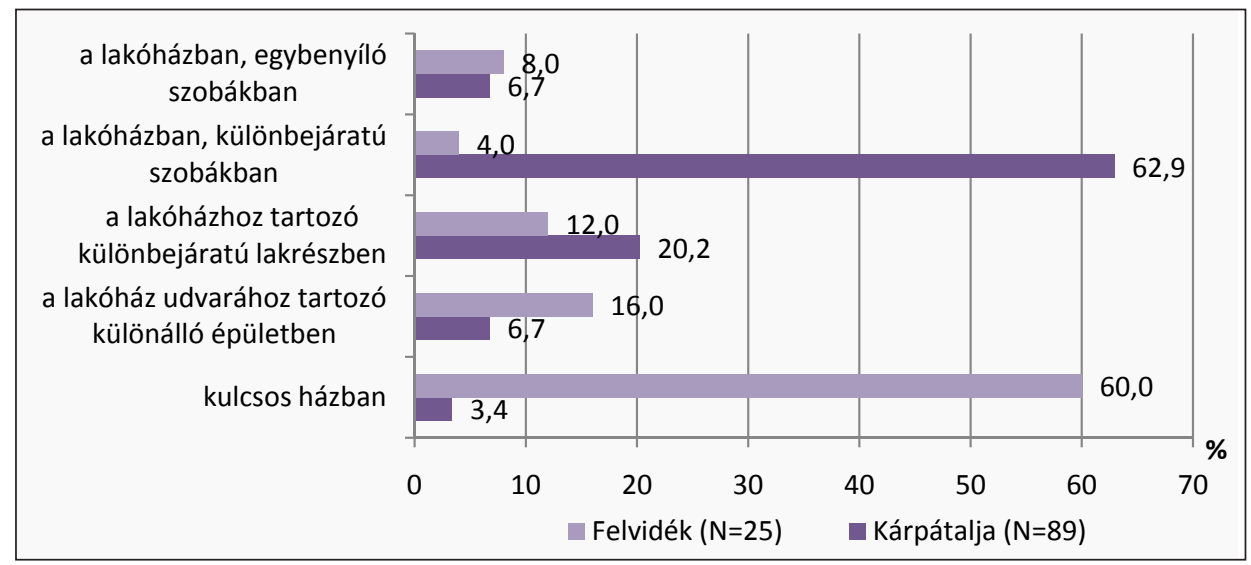

Forrás: Saját szerkesztés

A házak stílusát tekintve Kárpátalján főként a kockaházak (41,6\%), illetve a kétszintes $(34,8 \%)$ és az egyedi típusú lakóházak $(14,6 \%)$ szerepelnek kimagasló arányban, s nagyon kevés a hagyományos $(1,1 \%)$ vagy átépített parasztház $(4,5 \%)$. 


\section{TEMATIKUS TANULMÁNYOK - Kárpátalja társadalma}

Felvidéken viszont a legnagyobb arányban az átépített parasztházakat $(34,6 \%)$ használják vendégfogadásra. Kiemelkedő még a kétszintes lakóházakban $(19,2 \%)$ való vendégfogadás is.

A Felvidéken felmért 26 és Kárpátalján megvizsgált 89 vendégházban (4. táblázat) egy házra vonatkoztatva átlagosan 10,1 helyiség van, ebből Felvidéken 5,2 és Kárpátalján 4,8 a szobák száma, amelyből 4,5 és 3,0 szobát a vendégek fogadására használnak. Amíg a Felvidéken minden házban átlagosan 12,7 férőhely van, addig Kárpátalján ez az átlagszám csak 5,3. A pótágyak átlagszáma is hasonló arányokat mutat: 2,8 és 0,5 .

Felvidéken a vendégfogadásra használt házak 77\%-át csak a turisták használják, a házigazda nem abban a házban él. Állandó lakója (2-3 fó) csak a vendégházak 23\%-ának van. Kárpátalján pedig minden házban ott lakik a vendégfogadó és/vagy a családja.

4. táblázat. A vendégházak vendégszobáinak és férőhelyeinek száma a két célterületen

\begin{tabular}{|c|c|c|c|c|c|c|}
\hline \multicolumn{1}{|c|}{ Terület } & Vendégházak & Helyiségek & Szobák & $\begin{array}{c}\text { Vendég- } \\
\text { Szobák }\end{array}$ & Férôhely & Pótágyak \\
\hline Felvidék & 26 & 262 & 134 & 118 & 329 & 73 \\
\hline Kárpátalja & 89 & 895 & 431 & 269 & 473 & 44 \\
\hline
\end{tabular}

Forrás: Saját szerkesztés

Mivel a Felvidéken a vendégfogadók jelentős része vendégeitől teljesen külön épületben lakik, így egyértelmű, hogy az egészségügyi helyiségeket (fürdőszoba, WC) (2. ábra) is csak a vendégek részére alakították ki. A felvidéki vendégházak 65,4\%-ánál már minden szobához külön fürdőszoba és WC van, míg a többi esetben a vendégek részére közös használatú fürdőszoba és WC van kialakítva. A konyha használata is $80,8 \%$-ban csak a vendégeké. Az egyéb kategóriában a felvidéki vendéglátók a közeli éttermi étkezési lehetőséget említették meg főként.

Kárpátalján a legtöbb esetben a turisták a vendéglátókkal közösen használják a konyhát (78,7\%). A vendégházak közel felében a vendégek részére közös fürdőszoba és WC van kialakítva, míg közel hasonló arányban a házigazdákkal közösen használják azokat. (4. ábra). A szobánkénti külön fürdőszoba és WC kialakítása pedig a vendégházak alig 5\%-ánál fordul elő. Mindezek alapján arra lehet következtetni, hogy Kárpátalján a vendégházak elsősorban lakóházak és csak másodsorban funkcionálnak vendégházakként. 


\section{TEMATIKUS TANULMÁNYOK - Kárpátalja társadalma}

4. ábra. Milyen az egészségügyi helyiségek használata a vendégháznak (\%)

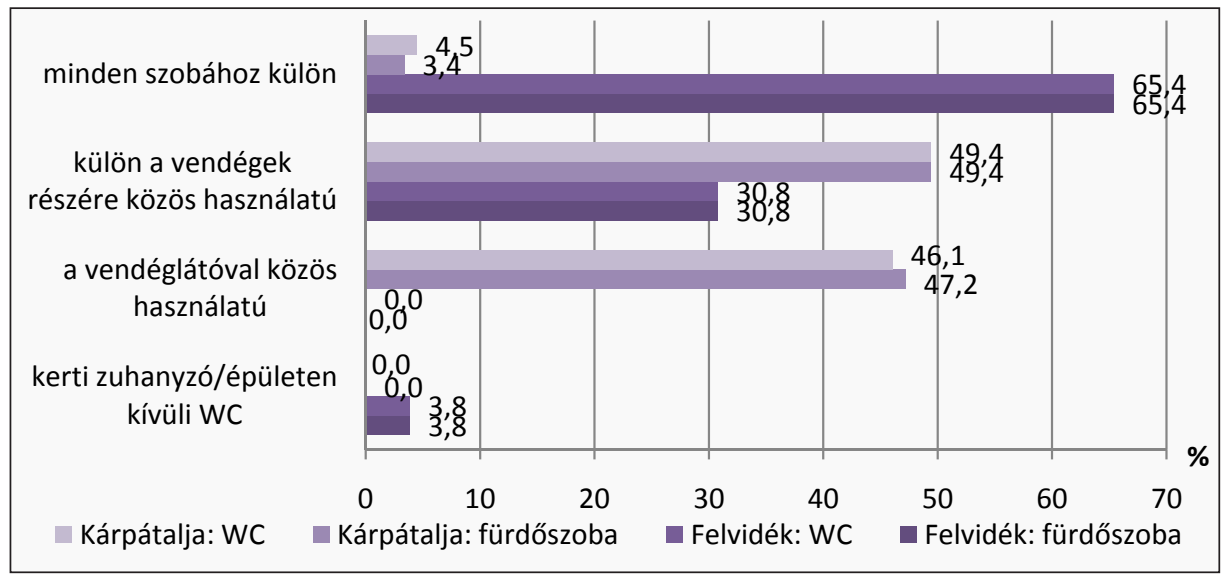

Forrás: Saját szerkesztés

A kutatásból az is kiderül, hogy a vendégfogadók mindkét területen saját házukat legtöbbször összkomfortosnak ítélik (5. táblázat). A vendégek számára a megbízható minőséget garantáló - Magyarországon és más nyugati államokban már régóta használatos - minősítési rendszer azonban még nincs elterjedve egyik vidéken $\mathrm{sem}^{5}$, hiszen a megkérdezett felvidéki ${ }^{6}$ vendégház-tulajdonosok 73,7\%-ának és a kárpátaljaiak $^{7}$ 62,9\%-ának nincs még minősítve a háza. A magyarországi napraforgós jelöléstől ugyan e vidékeken is használhatnak más jeleket a minősítésre, de erre utaló megjegyzést senki nem tett az egyéb kategóriában.

${ }^{5}$ Amint korábban említésre került, Szlovákiában létezik egyfajta állami minősítési rendszer, illetve Dél- Szlovákiában a Kultúráért és Turizmusért Társulás (Association for Culture and Tourism) is kidolgozott egy másik, a „REGIO DANUBIANA“ minősítési rendszert, amelynek jele a szitakötő. A kutatás viszont azt bizonyítja, hogy az általunk vizsgált vendégházak többsége ezek által még nem volt minősítve.

Ukrajnában állami szinten még nem sikerült minősítési rendszert kidolgozni, hanem csak civil szervezetek által kidolgozott minősítési rendszerek által kategorizálják a házakat.

${ }^{6}$ A felvidéki adatközlők közül heten nem válaszoltak a minősítéssel kapcsolatos kérdésre, így a százalékos arány a 19 adatközlő válasza alapján lett megállapítva.

${ }^{7}$ Akik Kárpátalján 2, 3 illetve 4 napraforgós minősítést jeleztek házuknál, azoknál a kétezres évek elején kísérleti jelleggel magyarországi mintára el volt végezve a napraforgós minősítés az adatközlők bevallása szerint. 
www. metszetek.unideb.hu

\section{TEMATIKUS TANULMÁNYOK - Kárpátalja társadalma}

5. táblázat. A vendégházak komfortfokozata és minősítése a két célterületen (\%)

\begin{tabular}{|l|c|c|c|c|c|c|c|c|c|}
\hline \multicolumn{9}{|c|}{ Komfortfokozat } & \multicolumn{6}{c|}{ Minősítés } \\
\hline Terület & $\begin{array}{c}\text { Komfort } \\
\text { nélküli }\end{array}$ & $\begin{array}{c}\text { Félkom- } \\
\text { fortos }\end{array}$ & $\begin{array}{c}\text { Komfor- } \\
\text { tos }\end{array}$ & $\begin{array}{c}\text { Összkom- } \\
\text { fortos }\end{array}$ & $\begin{array}{c}\text { 1 napra- } \\
\text { forgós }\end{array}$ & $\begin{array}{c}\text { 2 napra- } \\
\text { forgós }\end{array}$ & $\begin{array}{c}\text { 3 napra- } \\
\text { forgós }\end{array}$ & $\begin{array}{c}\text { 4 napra- } \\
\text { forgós }\end{array}$ & $\begin{array}{c}\text { Még nincs } \\
\text { minósítve }\end{array}$ \\
\hline Felvidék & 3,9 & 11,5 & 23,1 & 61,5 & 5,3 & 5,3 & 5,3 & 10,5 & 73,7 \\
\hline Kárpátalja & - & 5,6 & 14,6 & 79,8 & - & 2,2 & 31,5 & 3,4 & 62,9 \\
\hline
\end{tabular}

Forrás: Saját szerkesztés

A vendéglátóktól azt is megkérdeztük, hogy milyen ellátást kínálnak a vendégeiknek. Felvidéken többségében nincs ellátás $(61,5 \%)$ a vendégházaknál, vagy ha van, akkor teljes ellátás (27,0\%) vagy csak reggeliztetés (11,5\%). A kárpátaljai vendéglátók szeretik étellel-itallal ellátni vendégeiket, mivel a válaszadók fele $(51,7 \%)$ félpanziós ellátásban részesíti a turistákat. 27,0\%-uk a félpanziós ellátást uzsonnacsomaggal is kiegészíti, s vannak, akik teljes ellátást kínálnak nekik (13,5\%).

A vendéglátók által kínált programlehetőségek terén a két kutatóponton begyűjtött válaszok változatos képet mutatnak. Kárpátalján jóval több azok aránya, akik nem kínálnak vendégeiknek semmilyen programot. Felvidéken a megkérdezett vendégfogadók dominánsan a telken belül $(65,4 \%$, pl. medence használat, grillezés, szauna, fitnesz és sportolási lehetőségek) és 50 km-es körzetben $(57,7 \%)$ kínálják a legtöbb programot a turistáknak. A felvidékiek a helyi hagyományok bemutatására utaló programlehetőségeket, mint például disznóvágás, kézművesség, nagyon kevesen említették meg. Kárpátalján a kerti sütés-főzésen kívül a vendégeknek lehetőség nyílik a baromfiudvar megtekintésére, állatetetésre, kerti sétára, esetleg a vendégfogadó pincéjében borkóstolásra.

Kárpátalja esetében a településen belül, illetve a 100 km-es és annál távolabbi körzetben valamivel többen kínálnak programokat, mint Felvidéken. A nagyobb távolságban lévő programlehetőségek ajánlása abból fakad, hogy a magyar-ukrán határmentén lévő magyar falvakból csillagtúraszerűen elérhetőek a főbb nevezetességek, mint például a Vereckei-hágó, Munkács és a Munkácsi vár, Ungvár és az Ungvári vár, Rahó, Szinevéri-tó stb. Felvidéken mind az 50 km-es körzetben, mind pedig a 100 km-es s annál nagyobb körzetben történő programajánlásoknál a környező városok (Pozsony, Komárom, Nyitra, Léva stb.), termálfürdők (Párkány, Nagymegyer stb.), múzeumok és templomok (pl. Bényi rotunda) mellett magas arányban fordul elő magyarországi (esetleg ausztriai) programok és látnivalók ajánlása.

A vidéki turizmus egyik fő célja, hogy minél több ember részesüljön a turizmus jövedelemkiegészítő hatásából. A falusi turizmussal foglalkozó emberek nemcsak a szállásadásból, étkeztetésből és programok szervezéséből tudnak profitálni, hanem önmaguk által, a háztáji földeken megtermelt házi termékeiket is értékesíthetik. 


\section{TEMATIKUS TANULMÁNYOK - Kárpátalja társadalma}

A felvidékiek több mint fele (53,8\%), a kárpátaljaiaknak 4,5\%-a nem rendelkezik semmilyen házi termékkel. A kárpátaljaiak szinte minden termék előállítása és értékesítése tekintetében megelőzik a felvidékieket. A különböző házi finomságokat többnyire saját fogyasztásra készítik, termelik a gazdák, s amiből sok van, abból eladásra is jut. A legnagyobb arányban a lekvárt (37,1\%), házi bort (33,7\%) és pálinkát (24,7\%), a különböző húskészítményeket (18,0\%), a házi túrót és tejfölt (16,9\%), a friss gyümölcsöt és zöldséget $(13,5 \%)$, valamint ezek befőzött, savanyított $(12,4 \%)$ változatát tudják értékesíteni.

A házi termékek készítése mellett Kárpátalján az adatközlők 30,3\%-a, Felvidéken pedig 19,2\%-a készít népművészeti vagy kézműves tárgyakat. Előző esetében a legtöbben a rongypokróc/rongyszőnyeg $(14,6 \%)$, a szőttes $(7,9 \%)$ és a kivarrott abroszok, kendők $(5,6 \%)$ készítésével és értékesítésével foglalkoznak, míg utóbbi esetében mindet azonos arányban (3,8\%) készítik és értékesítik.

\subsection{SZOCIÁLIS HELYZET}

A felmérés alapján a felvidéki vendégfogadók szociális helyzete stabilnak mondható, hiszen az adatközlők többsége (92,3\%) esetében a vele egy háztartásban élő munkaképes családtagok mindegyikének van állandó munkahelye. Kárpátalján ezt csak az adatközlők 37,1\%-a válaszolta. Mindenképpen figyelembe kell venni, hogy a kárpátaljai adatfelvétel 2009-ben és 2011-ben zajlott, amikor még Ukrajna viszonylag stabilabb gazdasági helyzetben volt. Napjainkban viszont a 2014-ben kezdődött kelet-ukrajnai fegyveres konfliktus miatt a gazdaság a csőd szélére került, a nemzeti valuta elértéktelenedett, az energiahordozók és a közüzemi díjak drasztikusan emelkedtek, a külföldi turisták pedig huzamosabb időre elkerülték az országot, így Kárpátalját is. Ebből kifolyólag az évekig sok családnak stabil jövedelmet biztosító falusi turizmus is nehéz helyzetbe került és vele együtt a családok is. Napjainkban tehát elképzelhető, hogy a munkaképes családtagok még kevesebb arányban rendelkezhetnek munkahellyel, s kényszerülnek külföldi munkavállalásra.

A kárpátaljai vendégfogadók 41,6\%-ának a turizmuson kívül van egyéb mellék/ kiegészítő jövedelemforrása, melyek között leggyakrabban a mezőgazdaságot, növénytermesztést és állattenyésztést említették meg, amelyek nagyon jól illeszkednek a falusi vendéglátói tevékenységhez. Felvidéken az adatközlők 73,1\%-a válaszolta azt, hogy a turizmuson kívül van mellékjövedelme, de szinte mindenki az állandó munkahelyét említette meg. Tehát ez az adat nem releváns. 


\section{TEMATIKUS TANULMÁNYOK - Kárpátalja társadalma}

5. ábra. Miért kezdett el falusi vendéglátással foglalkozni? (\%)

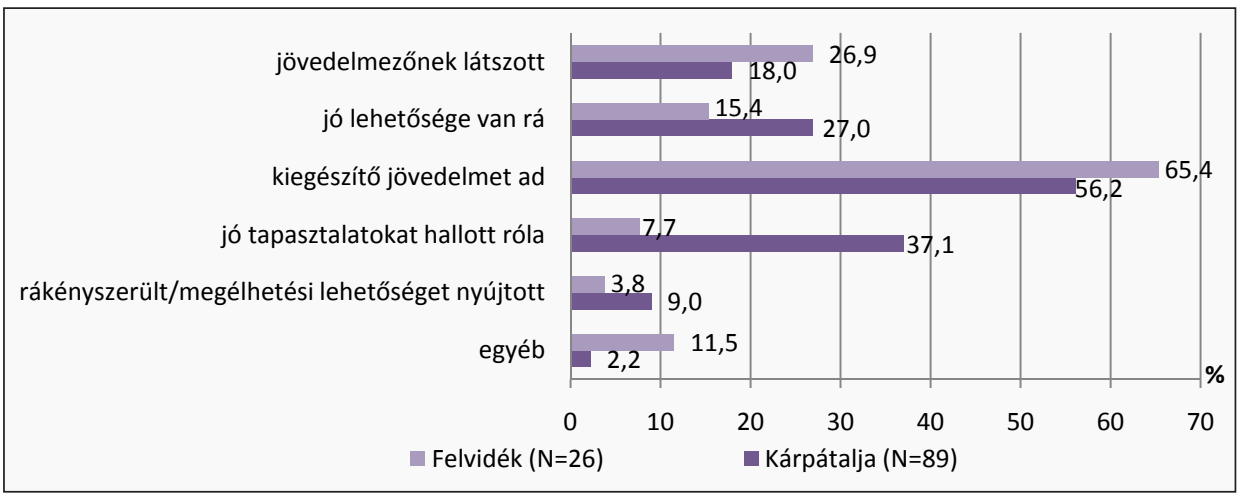

Forrás: Saját szerkesztés

A megkérdezett adatközlők vendégfogadásba való bekapcsolódásuk okaként több választ is megjelölhettek. Ennek alapján a legtöbben mindkét célterületen azért kezdtek el falusi turizmussal foglalkozni, mert kiegészítő jövedelemhez juthattak (65,4\% és 56,2\%) e tevékenység által (5. ábra). A kárpátaljai adatközlők sokan említették még a másoktól hallott jó tapasztalatokat $(37,1 \%)$, valamint többen azt a lehetőséget használták ki (27,0\%), hogy a településen szerveződőben volt a falusi turizmus és bekapcsolódtak. A foglalkozás jövedelmezősége második legfontosabb motivációként jelenik meg a felvidékieknél (26,9\%), amíg a kárpátaljaiaknál csak a 4. helyen áll (18,0\%). A tény, hogy viszonylag csak keveseket vezérelt a kényszerűség mindkét területen (3,8\% és 9,0\%), pozitívumnak könyvelhető el.

A kárpátaljai falusi vendégfogadók fontosnak tartották, hogy a turizmusba bekapcsolódva, szolgáltatásuk színvonalának emelése érdekében szakirányú végzettséget szerezzenek. A túlnyomó többség (61 fö) turisztikai tanfolyamot végzett, s akadt olyan vendéglátó is, akinek főiskolai vagy egyetemi turisztikai végzettsége volt ( 2 fó). A végzettséggel nem rendelkezők közül 20-an szeretnék a jövőben pótolni ezt a hiányosságot. Felvidéken a megkérdezettek többsége úgy gondolja, hogy nincs szüksége (12 fô) semmilyen turisztikai végzettségre tevékenysége végzéséhez, vagy éppen nincs ideje rá (3 fő), illetve nincs hol megszerezni a végzettséget (3 fő). E döntő többségű válasz mellet azért voltak, akik tanfolyammal ( 5 fő) és főiskolai végzettséggel (1 fö) rendelkeztek, illetve akik szeretnék pótolni ezt a hiányosságot ( 2 fó).

Mindkét kutatási terület esetében a falusi vendéglátók nagyon kevesen építkeztek tudatosan a falusi turizmusba való belépés miatt, hanem inkább a melléképületek átalakítása révén próbálták lakásukat a turisták igényeihez megfelelővé tenni. A legtöbben Kárpátalján kisebb belső felújításokat $(71,9 \%)$, telekszépítést $(52,8 \%)$ végeztek és a lakás komfortfokozatát igyekeztek emelni $(36,0 \%)$, valamint sokan házuk külső reno- 


\section{TEMATIKUS TANULMÁNYOK - Kárpátalja társadalma}

válását (33,7\%) is elvégezték. A jövőre vonatkozó terveik is hasonlóan alakulnak, mint az elvégzettek. Felvidéken a falusi turizmus érdekében elvégzett és tervezett fejlesztések, habár arányaiban többnyire alulmaradnak a kárpátaljai értékektől, mégis hasonló tendenciát mutatnak.

Felvidéken a falusi vendéglátók tevékenységük sikeresebb és eredményesebb végzéséhez elsősorban a marketing és reklámtevékenység $(60,0 \%)$ terén látnák a legnagyobb szükségét a segítségnek. Kárpátalján szinte azonos arányban jelölték meg a szálláshelyfejlesztést $(37,1 \%)$, illetve a marketinget és reklámozást $(36,0 \%)$. A programok szervezésében és szélesebb programkínálat kialakításában való segítséget mindkét területen közel azonos arányban gondolták fontosnak. A képzésben és felkészítésben való segítséget a felvidékiek nem igénylik, nem tartják szükségesnek. A kárpátaljaiak pedig, mint a korábbiakban láttuk is, többségben rendelkeznek valamilyen turisztikai képzettséggel.

A segítségnyújtást a kárpátaljai falusi vendégfogadók elsősorban a falusi turizmus helyi szervezőjétől $(41,6 \%)$ várják. A helyi önkormányzatnak $(23,6 \%)$ és a falusi turizmus különböző (helyi, járási, megyei stb.) szervezeteinek (16,9\%) tulajdonítanak még nagyobb jelentőséget, mivel a fontossági sorrend felállításánál ezeket tették a 2. és 3. helyre. A pályázatokat a válaszadók csak 10\%-a nevezte meg, mint kiemelt fontosságú segítségnyújtási lehetőséget. A felvidéki adatközlőknél ez pont fordítva van. A legtöbben $(30,8 \%)$ a legnagyobb jelentőséget a pályázati úton történő segítségnyújtásnak tulajdonítanak. Sikeres pályázati elbírálásban az elmúlt években többen is részesültek a Felvidéken, így nem csoda, ha a jövőre nézve is ebben bíznak. Mivel Szlovákia az EU tagja, így a felvidéki magyar vendéglátóknak több lehetőségük nyílik vállalkozásfejlesztési pályázatokra, mint kárpátaljai sorstársaiknak. Felvidéken a 2. kiemelt fontosságú helyen a helyi önkormányzat (26,9\%) áll, hasonlóan a kárpátaljai mintához, a 3. helyen pedig az utazási irodák (15,4\%).

\subsection{A TELEPÜLÉSEK FELKÉSZÜLTSÉGE, ALKALMASSÁGA A TURIZMUSRA}

A felmérés szempontjából fontosnak láttam megkérdezni a vendégfogadóktól, hogy milyen kiemelt vonzástényezőre alapozzák vállalkozásukat. A válaszadóknak a három legfontosabb válaszlehetőséget kellett megjelölni (6. ábra). Az adatközlők döntő többsége Kárpátalján azt válaszolta, hogy vállalkozásukat főként vendégszeretetükre $(84,3 \%)$ alapozzák. Ezen kívül még sokan fontosnak tartották a természeti környezetet $(73,0 \%)$, valamint a történelmi helyeket, hagyatékokat $(40,4 \%)$. Felvidéken a legtöbben két választ jelöltek meg azonos arányban, s ezáltal hasonlóan vélekednek, mint a másik kutatóponton: vendégszeretetüket és a természeti környezetet $(61,5 \%)$ tartják ők is a legfontosabb vonzástényezőnek. Harmadik helyen viszont náluk a kulturális értékek és a hagyományok (53,8\%) állnak, míg a Kárpátalján pre- 


\section{TEMATIKUS TANULMÁNYOK - Kárpátalja társadalma}

ferált történelmi helyeket, hagyatékokat csak nagyon csekély mértékben méltatták $(3,8 \%)$. Továbbá a felvidékiek a saját szervezésű programokat is magas vonzástényezőnek tartják. Annak ellenére, hogy Dél-Szlovákia Kárpátaljánál fejlettebb borkultúrával rendelkezik, mégis kevesebben alapozzák a turisztikai tevékenységüket a szőlővel, borral összefüggő kínálatokra (11,5\%), mint Kárpátalján (21,3\%).

6. ábra. Milyen kiemelt vonzástényezőre alapozza vállalkozását? (\%)

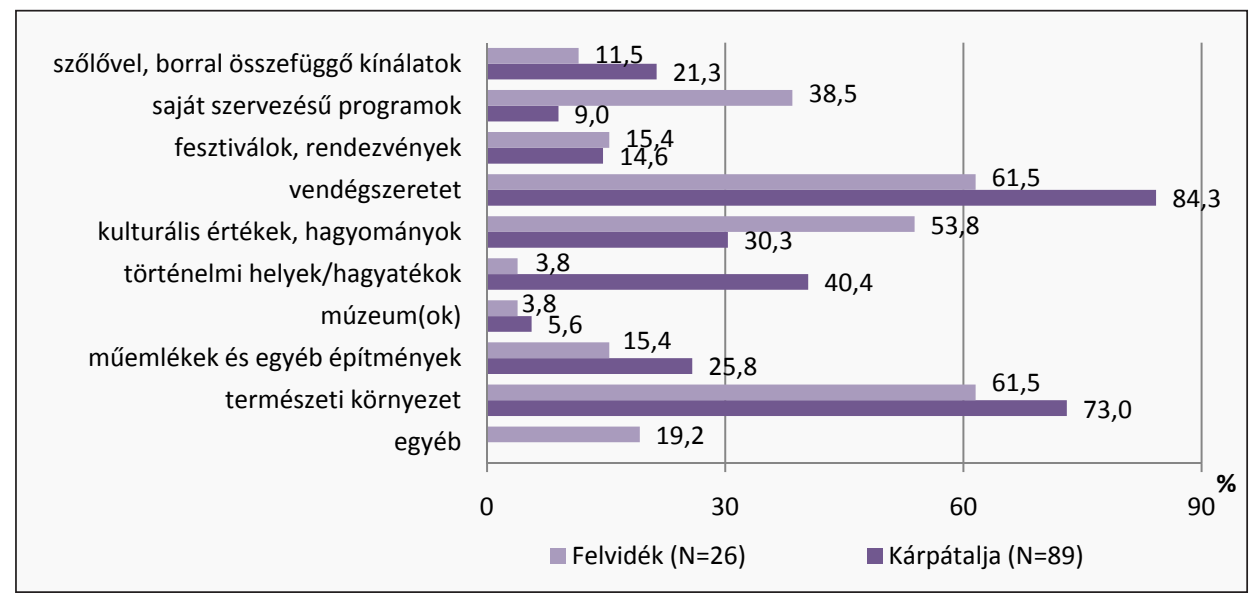

Forrás: Saját szerkesztés

Arra a kérdésre, hogy a „Települését alkalmasnak ítéli-e a vendégek fogadására a lakosság oldaláról, szemszögéből?", mindkét kutatóterület 29 településén egyértelműen igennel válaszoltak. Egyedül a kárpátaljai Mezővári településen 3 vendégfogadó jegyezte meg, hogy a lakosság nem igyekszik rendezetté tenni a települést.

A vizsgálatban 22 felvidéki és 7 kárpátaljai településről kerültek ki az adatközlő falusi vendéglátók. Véleményük alapján Felvidéken a turizmus „,közepesen” (53,8\%) múködik, a „jól”, illetve „nem jól” kategóriák pedig azonos értékelést kaptak (19,2\%). Kárpátalján a mérleg inkább a pozitív oldalra billen. A „közepesen” és a „jól” kapott közel azonosan kiemelkedő értékelést (42,7\% és 40,4\%), illetve a „kiválóan” értékelést négyszer nagyobb arányban jelölték itt, mint Felvidéken (7. ábra).

A kárpátaljai adatközlők 73,0\%-a és a felvidékiek 80,8\%-a szerint a települések önkormányzata semmilyen segítséget nem nyújt a falusi turizmusba bekapcsolódó embereknek. Akik az ellenkezőjét állítják, azok szerint a Felvidéken az önkormányzat segít reklámozni a falut, programokat szervez, kerékpárutat biztosít. Kárpátalján az önkormányzatok segítségnyújtása fóként a közösségi épületek (kultúrház) kölcsönadásában merül ki, ahol a vendégek részére zenés estéket stb. szerveznek, s 


\section{TEMATIKUS TANULMÁNYOK - Kárpátalja társadalma}

néhányan itt is megemlítették a rendezvényszervezést, reklámozást, a testvérvárosi kapcsolatépítést, s néhol a polgármester kapcsolatai által érkeznek a vendégek a településre.

7. ábra. Hogyan müködik a turizmus a településen? (\%)

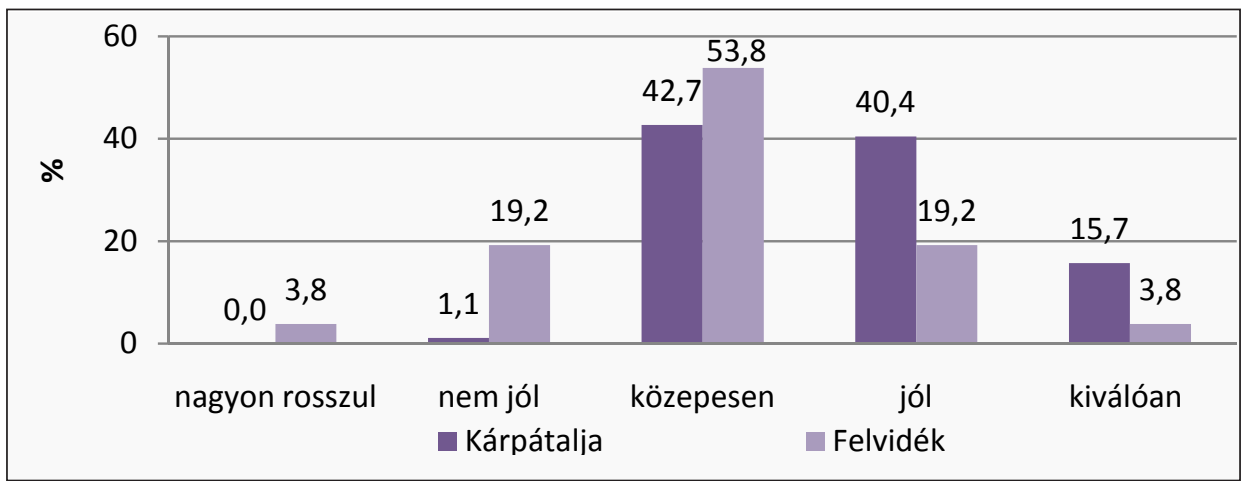

Forrás: Saját szerkesztés

A vizsgálat során azt is szerettem volna megtudni, hogy az adatközlők miként vélekednek településükről, milyen területen látják a fejlesztések szükségességét ${ }^{8}$ a legfontosabbnak. A 6. táblázat alapján elmondható, hogy Felvidéknél minden esetben alacsonyabb átlagszámok jelennek meg, mint Kárpátalja esetében. Ez főként abból fakadhat, hogy úgy Szlovákia, mint a Felvidék egy magasabb gazdasági színvonalat képvisel, egy szervezettebb szociális és egy fejlettebb, kiépített infrastrukturális hálóval rendelkezik. Ennek köszönhetően ők valamivel elégedettebbek is településük fejlettségi szintjével. Amiben viszont teljesen egyetértenek a kárpátaljaiakkal, hogy a turizmus fejlesztését nagyon fontos lenne támogatni. Nyilván ez jelenti számukra a megélhetésük egy részét, ezért is tartják ilyen fontosnak. A kárpátaljai vendéglátók szerint halaszthatatlan lenne településükön a szemét, a szennyvíz és az ivóvízhálózat kiépítése, ami nem csak a helyi lakók érdekeit, de az oda érkező turisták komfortérzetét is fokozná. Felvidéken az imént említett közműszolgáltatásoknak nem a kiépítésén, hanem a fejlesztésén van a hangsúly, de azt sem tartják az adatközlők halaszthatatlan fontosságúnak. Mindkét területen magas pontszámokat kapott a

${ }^{8}$ A vendéglátóknak egy három fokú skálán kellett a felsorolt fejlesztési lehetőségeket rangsorolni, ahol 1 azt jelentette „nem fontos”, 2 azt, hogy „fontos, de nem halaszthatatlan”, a 3 pedig, hogy „nagyon fontos". A kapott értékekből átlagot vontunk. Minél nagyobb a kapott átlagszám, a válaszadók szerint annál fontosabb és szükségszerübb az említett fejlesztési lehetőség elvégzése. 
www. metszetek.unideb.hu

\section{TEMATIKUS TANULMÁNYOK - Kárpátalja társadalma}

környezet rendbetétele, a munkahelyteremtés, a természeti értékek megóvása és a közutak rendbetétele.

6. táblázat. Ön szerint mit kellene településén fejleszteni? ( $\mathrm{F}=$ Felvidék $(\mathrm{N}=26), \mathrm{K}=$ Kárpátalja $(\mathrm{N}=89)$ )

\begin{tabular}{|c|c|c|c|c|c|}
\hline \multirow[t]{2}{*}{ Fejlesztési lehetőség } & \multicolumn{2}{|c|}{$\begin{array}{l}\text { Átlag- } \\
\text { számok }\end{array}$} & \multirow[t]{2}{*}{ Fejlesztési lehetőség } & \multicolumn{2}{|c|}{$\begin{array}{l}\text { Átlag- } \\
\text { számok }\end{array}$} \\
\hline & $\mathrm{F}$ & $\mathrm{K}$ & & $\mathrm{F}$ & $\mathrm{K}$ \\
\hline 1. A turizmus támogatása & 2,8 & 2,8 & $\begin{array}{l}\text { 16. Településszépítés, } \\
\text { virágosítás }\end{array}$ & 2,1 & 2,7 \\
\hline $\begin{array}{l}\text { 2. A mezőgazdaság általános } \\
\text { fejlesztése }\end{array}$ & 2,1 & 2,7 & $\begin{array}{l}\text { 17. A közlekedési kapcsolatok } \\
\text { fejlesztése }\end{array}$ & 2,2 & 2,6 \\
\hline $\begin{array}{l}\text { 3. A kereskedelem-vendéglátás } \\
\text { fejlesztése }\end{array}$ & 2,4 & 2,7 & 18. A közutak rendbetétele & 2,5 & 2,9 \\
\hline 4. Az oktatás fejlesztése & 2,0 & 2,7 & $\begin{array}{l}\text { 19. Az egészségügyi ellátás } \\
\text { fejlesztése }\end{array}$ & 2,0 & 2,6 \\
\hline 5. Vállalkozók támogatása & 2,5 & 2,7 & 20. A közbiztonság javítása & 1,9 & 2,0 \\
\hline 6. Munkahelyteremtés & 2,6 & 2,9 & $\begin{array}{l}\text { 21. A szórakozási lehetőségek } \\
\text { bővítése }\end{array}$ & 2,3 & 2,6 \\
\hline 7. A kultúra támogatása & 2,4 & 2,8 & $\begin{array}{l}\text { 22. A lakáskörülmények } \\
\text { javítása }\end{array}$ & 1,7 & 2,5 \\
\hline $\begin{array}{l}\text { 8. Ipari és más beruházások } \\
\text { megszerzése }\end{array}$ & 2,1 & 2,6 & $\begin{array}{l}\text { 23. Helyi építészeti értékek } \\
\text { védelme }\end{array}$ & 2,0 & 2,7 \\
\hline $\begin{array}{l}\text { 9. A szociális támogatások } \\
\text { bővítése }\end{array}$ & 1,8 & 2,6 & $\begin{array}{l}\text { 24. A természeti értékek } \\
\text { megóvása }\end{array}$ & 2,6 & 2,8 \\
\hline 10. A környezet rendbetétele & 2,7 & 2,9 & $\begin{array}{l}\text { 25. A helyi sportélet } \\
\text { fejlesztése }\end{array}$ & 2,0 & 2,6 \\
\hline 11. A közvilágítás fejlesztése & 2,0 & 2,2 & 26. A távközlés fejlesztése & 1,7 & 2,3 \\
\hline $\begin{array}{l}\text { 12. Az ivóvízhálózat a) fejlesztése } \\
\text { b) kiépítése }\end{array}$ & 1,6 & 2,8 & $\begin{array}{l}\text { 27. Kábeltévé hálózat fejlesz- } \\
\text { tése }\end{array}$ & 1,4 & 2,1 \\
\hline $\begin{array}{l}\text { 13. A szennyvízhálózat } a \text { ) fejlesz- } \\
\text { tése } b \text { )kiépítése }\end{array}$ & 1,8 & 3,0 & $\begin{array}{l}\text { 28. Internet kiépítés fejlesz- } \\
\text { tése }\end{array}$ & 1,7 & 2,4 \\
\hline $\begin{array}{l}\text { 14. A gázhálózat a) fejlesztése } \\
\text { b) kiépítése }\end{array}$ & 1,6 & 1,6 & 29. Vendégfogadók érdekkép- & 22 & 6 \\
\hline $\begin{array}{l}\text { 15. A szemétszállítás a) fejleszté- } \\
\text { se } b \text { ) kiépítése }\end{array}$ & 2,0 & 3,0 & & 2,3 & 2,0 \\
\hline
\end{tabular}

Forrás: Saját szerkesztés 


\section{TEMATIKUS TANULMÁNYOK - Kárpátalja társadalma}

\subsection{VENDÉGEK, FORGALOM, SZEZONALITÁS}

Az adatközlők bevallása szerint mindkét kutatási területen a nyári hónapok jelentik az év legforgalmasabb időszakát (8. ábra). Kárpátalján a június, július és augusztus, Felvidéken pedig főként a július és augusztus a legszámottevőbb. A nyári csúcsforgalmat egy erős előszezon (április, május, Felvidék esetében a június is ide tartozik) előzi meg, és egy gyengébb utószezon (szeptember, október) követi. Felvidéken a téli időszakban (december, január) megfigyelhető még egy jelentősebb forgalomnövekedés.

8. ábra. Mikor, melyik hónap(ok)ban van a legnagyobb forgalma? (\%)

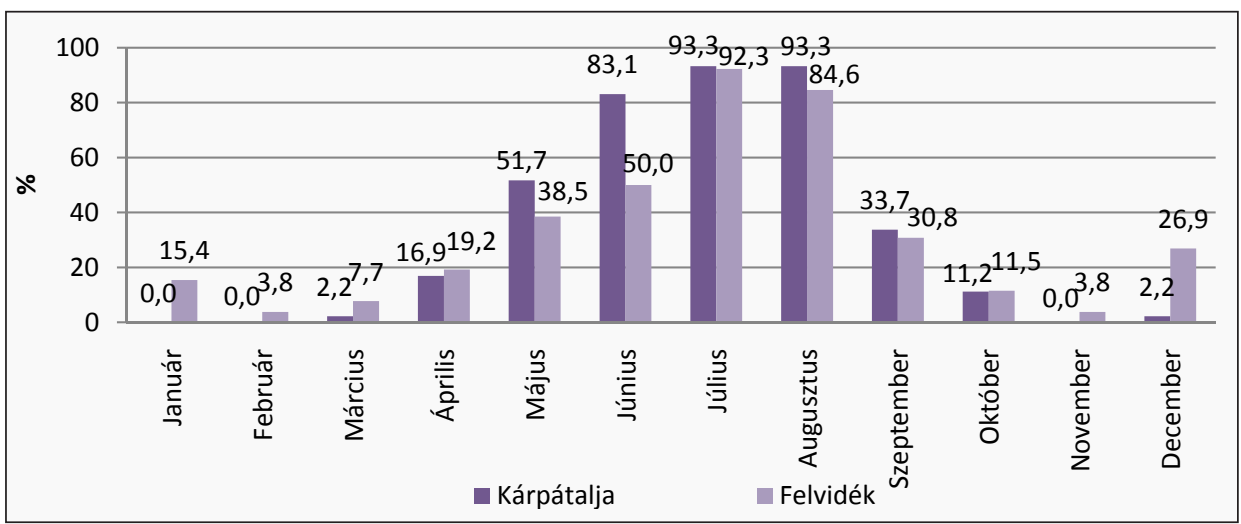

Forrás: Saját szerkesztés

A vendégek típusát tekintve Felvidéken határozottan a pihenő, de a környéket felfedezni vágyó $(73,1 \%)$ turistát kedvelik a legjobban, illetve azt, amelyik viszsza is tér hozzájuk $(65,4 \%)$. Kárpátalján is hasonlóan vélekednek, viszont amíg ők nem igazán kedvelik a pihenő, otthonülő vendéget $(2,2 \%)$, addig a Felvidéken ez nem okoz gondot (30,8\%). Ez valószínúleg abból adódik, hogy Kárpátalján a vendégek a házigazdával közös házban, portán tartózkodnak - a Felvidéken ez nem jellemző - és a mindennapi tevékenység elvégzésében akadályozhatják az otthonülő turisták.

A célterületre érkező vendégeket a felvidéki válaszadók többsége külföldről és belföldről (76,9\%), míg a kárpátaljaiak 56,2\%-a csak külföldről és 44,3\%-uk belés külföldről egyaránt várja. A belföldi vendégvárásnál mindkét vizsgált terület adatközlői saját országuk egész területéről várják a vendégeket. A külföldi vendégeket a Felvidéken főként Magyarországról, Csehországból és Lengyelországból várják. Kárpátalján legtöbben Magyarországról várják a külföldi vendégeket. Az 


\section{TEMATIKUS TANULMÁNYOK - Kárpátalja társadalma}

elvárásoknak megfelelően a turisták pontosan a vendégfogadók által megnevezett belföldi és külföldi területekről, országokból érkeznek. Felvidéken a válaszadók ( $\mathrm{N}=22)$ szerint a külföldi turisták között a magyar $(59,1 \%)$, cseh $(45,5 \%)$ és lengyel $(40,9 \%)$ turista a leggyakoribb, Kárpátalján $(\mathrm{N}=89)$ pedig a magyar vendégfogadók domináns küldő országa Magyarország (96,6\%).

\subsection{A FALUSI TURIZMUS SZERVEZETTSÉGE ÉS A REKLÁMTEVÉKENYSÉG}

Felvidéken a vendéglátók 57,7\%-a és Kárpátalján 29,2\%-a nem tagja semmilyen turisztikai szervezetnek. A vendégfogadók többsége Felvidéken a helyi szervezetekhez csatlakozik $(30,8 \%)$, míg Kárpátalján járási szervezet tagjai $(52,8 \%)$. A kárpátaljaiak közül szinte senki nem lépi túl a járási szintet, addig Felvidéken többen is rendelkeznek regionális és országos tagsággal is. Akik tagok, azok mindkét területen többnyire hasznosnak ítélik a tagságot.

Forgalmuk növelése érdekében Felvidéken a vendégfogadók 42,3\%-a, Kárpátalján 36,0\%-a kapcsolatot létesített idegenforgalmi szervező irodákkal. Ezen kívül vállalkozásuk reklámozása érdekében néhányan önálló szállásadói kiadványnyal is rendelkeznek - Felvidéken jóval többen $(26,9 \%)$, mint Kárpátalján $(4,5 \%)$. A falusi vendégfogadók által lakott településekről Kárpátalján 83,1\%-ban készült turisztikai jellegű és a falusi turizmust reklámozó kiadvány. Itt többnyire a válaszadók településenkénti közös prospektusáról van szó, melyen röviden bemutatják a települést és reklámozzák szolgáltatásaikat. Felvidéken ez az arány jóval kevesebb: $38,5 \%$.

$\mathrm{Az}$ internet nyújtotta lehetőségek következtében nem csak a szervezetek, közösségek, esetleg utazási irodák tudják a falusi turizmus magánszálláshelyeit reklámozni, hanem maguk a vendéglátók is megtehetik azt. Internetes hozzáférhetőséggel a Felvidék vendéglátóinak 84,6\%-a és önálló honlappal pedig 57,7\%-a rendelkezik. Kárpátalján ugyanez az arány jóval kevesebb: 51,7\% és 17,9\%. Ettől függetlenül a megkérdezettek vendégházai és az általuk nyújtott szolgáltatások megtalálhatók az Interneten egy (Felvidék: 30,8\%, Kárpátalja: 51,7\%) vagy akár több honlapon is (Felvidék: 61,5\%, Kárpátalja: 38,2\%). 
www. metszetek.unideb.hu

\section{TEMATIKUS TANULMÁNYOK - Kárpátalja társadalma}

\section{SWOT-analízis}

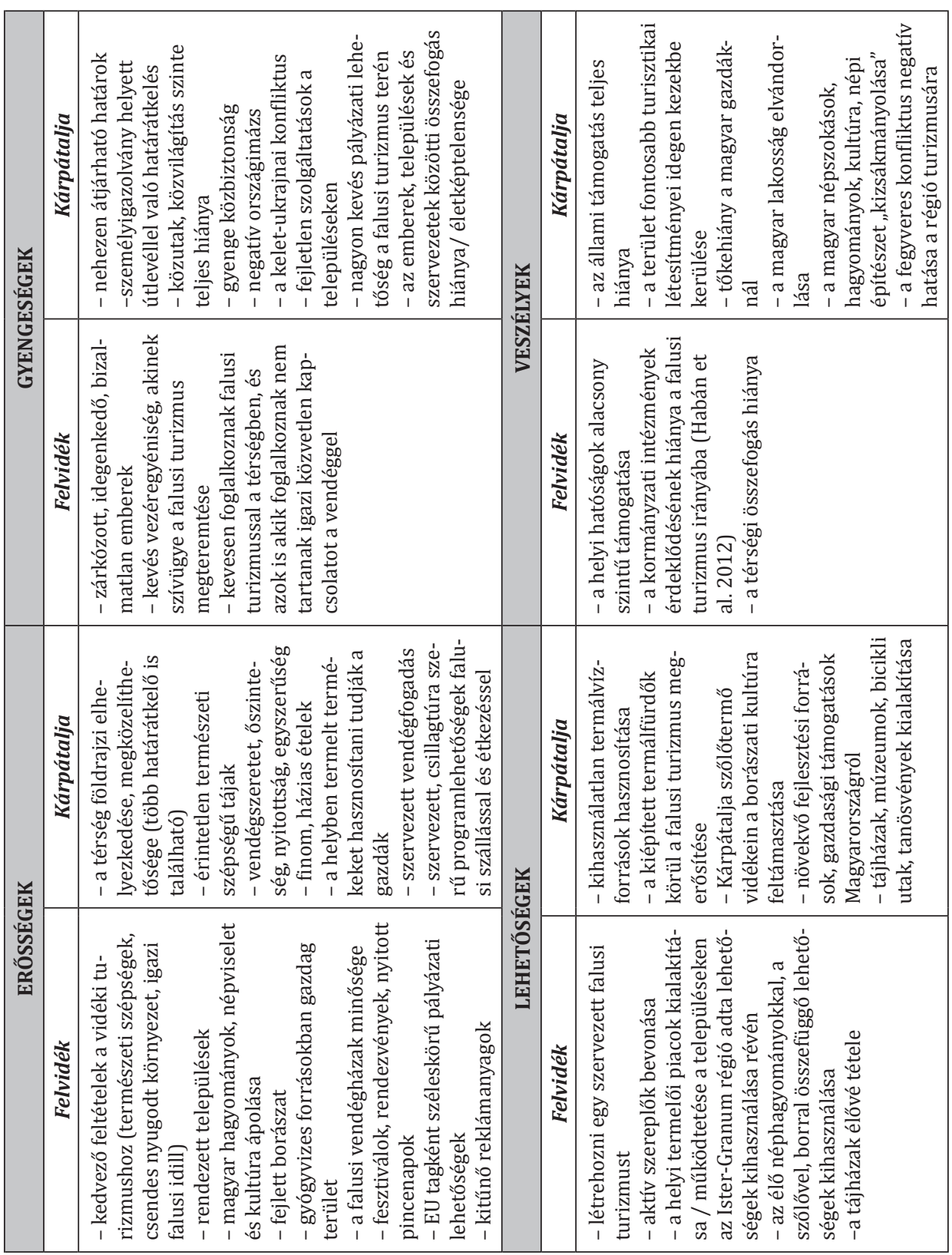




\section{TEMATIKUS TANULMÁNYOK - Kárpátalja társadalma}

\section{7. Összegzés}

A 2014-es év folyamán mindkét régió esetében született egy gazdasági fejlesztési terv: a Baross Gábor Terv (Dél-Szlovákia/Felvidék) (Boros 2014) és az Egán EdeTerv (Kárpátalja) (URL 1, 2016.). A Baross Gábor Tervben egyértelműen megfogalmazzák, hogy a turizmus lehet a Felvidék számára az egyik kitörési pont. A fejlesztési tervben többször is megemlítik az általunk vizsgált falusi turizmust. A legtöbb esetben úgy jellemzik, hogy több járásnak is vannak kiváló adottságai, megfelelő feltételei a vidéki turizmushoz. Az egyik fontos fejlesztési iránynak jelölik meg a falusi/agroturizmusban rejlő potenciál kihasználását a vidékfejlesztés szempontjából. Kárpátalján az Egán Ede-Tervben szintén kiemelik a turizmust, mint a vidék egyik fontos kitörési pontját. Ezen belül hangsúlyozzák a falusi turizmus fontosságát, és úgy jellemzik, mint az egyik legjobban szervezett, élő, működő turisztikai tevékenységet, ami elsősorban mint falusi szállásadás működik, és a jövőre nézve a falusi turizmust, mint turisztikai terméket tovább kell fejleszteni.

A falusi turizmussal kapcsolatos vizsgálat során, ahogy az adatok elemzésével, összehasonlításával folyamatosan haladtam előre, egyre nyilvánvalóbbá vált, hogy a kutatott területeken a falusi vendéglátás eltérő szervezettségi szinten van, és eltérő formában működik. Talán klasszikus értelemben egyik területen sem lehet az „igazi” falusi turizmussal azonosítani e tevékenységeket. Bár a szállás falusi környezetben valósul meg, de a szállásadási szolgáltatás alapját nem egy mezőgazdasági tevékenység adja, illetve egyik helyen sem kapcsolódik hozzá bőséges vidéki, mezőgazdasági programkínálat, valamint az étkeztetés sem szokványos, falusi turizmusra jellemző módon történik. Szabó Bernadett (2009) szerint pedig a falusi turizmus a szállásadással, étkeztetéssel és programkínálattal együtt teljes.

A vizsgálat alapján elmondható, hogy a felvidéki szállások minőségesebbek, mint a kárpátaljaiak, mivel sokkal jobb a vendégházak fürdőszobával, WC-vel és konyhával való ellátottságuk. A vendégházak befogadóképessége/kapacitása és a pótágyazási lehetőség is sokkal nagyobb itt, viszont Kárpátalján egy településen belül több család foglalkozik a falusi vendéglátással, mint Felvidéken, így sokkal több családnak nyújt jövedelem-kiegészítést. Felvidéken a kulcsos házak vannak többségben, Kárpátalján pedig saját lakóházukban fogadják a vendégeket.

A programlehetőségeket tekintve Kárpátalján kevés idő van az adott település, többnyire csak lokális jelentőséggel bíró, értékeinek megismerésére, vidéki programokon való részvételre, mint például egy disznóvágás vagy esetleg lovaglás, állatgondozás. A jellemzően csoportosan érkező turistáknak a régió természeti és kulturális értékei csillagtúra szerűen kerülnek bemutatása és csak a szállás, étkezés történik a falusi turizmus helyén. Ezért látogatnak Kárpátaljára a vendégek, nem pedig a vidéki életmód felfedezéséért. Felvidéken jóval több programot kínálnak a vendégeknek a vendégház és udvar területén belül, de azok nem azonosíthatóak a tipikus falusi programokkal. 


\section{TEMATIKUS TANULMÁNYOK - Kárpátalja társadalma}

A falusi, hagyományos, autentikus ízek megismerésére Kárpátalján nagyobb lehetőség van, mint a Felvidéken, hiszen itt többnyire a vendégek a vendéglátó által készített ételeket fogyasztják, de az ételkészítési folyamatba a vendégek nem kapcsolódnak be, hiszen nagyon kevés időt töltenek a faluban. Felvidéken pedig a vendégek többsége önellátó, tehát a helyi hagyományos ízeket a vendéglátó által nincs módjukban megismerni.

A kapott eredmények nyilván egy helyzetképet mutatnak a két vizsgált területről. Nem felétlenül kell azt mondanunk, hogy a falusi turizmus múködése egyik vagy másik területen az kiváló vagy éppen nem megfelelő. Inkább azt lehet mondani, hogy sajátos, egyéni és a mindennapok eseményei és a terület adottságai alakították, illetve folyamatos változáson megy keresztül a jelentkező igényeknek megfelelően. Lehet, hogy nem hordozzák magukban a tipikus falusi turizmus minden vonásait, de például a kárpátaljai magyar családok számára mindenképpen érezhető a tevékenység pozitív hatása, ami főképpen a következőkben nyilvánul meg:

- a családok helyben való boldogulását, megmaradását ösztönzi, támogatja a falusi vendégfogadásból származó kiegészítő jövedelem;

- a családi gazdaságban megtermelt termékeket fel tudják használni a turisták étkeztetése során, illetve bizonyos készterméket akár árusíthatnak is (lekvár, pálinka stb.);

- a falusi vendégforgalomnak köszönhető, hogy a vidéken ismét éledezik a borkultúra, a kézműves termékek előállítása, értékesítése, a magyar népszokások, néphagyományok felelevenítése, megőrzése;

- a falusi turizmus helyi szinten való jó szervezettségének eredménye, hogy néhány településen a vendégéjszakák meghosszabbítása érdekében a falusi életmód sajátosságaira alapozott fesztiválokat hoztak létre (pl.: Lekvárfőző Fesztivál).

Mindezen pozitív hatásokat figyelembe véve ki lehet jelenteni, hogy Kárpátalján a magyar vendégfogadó családok számára kitörési pontnak és fontos megélhetési tényezőnek számít a falusi turizmus.

Felvidék szempontjából másabb kép rajzolódik ki. A falusi turizmus Felvidék, azon belül is a vizsgált tömbmagyarság lakta terület és annak vonzáskörzete turizmusában nem játszik meghatározó szerepet. Bár évek óta hangsúlyozzák a vidéki területek falusi vagy agroturisztikai hasznosításának pozitív hatásait, mégis kevés azoknak a magyar családoknak a száma, akik megpróbálták kihasználni a környezet nyújtotta lehetőségeket. Ennek ellenére azt lehet mondani, hogy akik részt vettek a kérdőíves felmérésben, azok jól végzik a munkájukat, megfelelő színvonalú szolgáltatást nyújtanak. 
www. metszetek.unideb.hu

\section{TEMATIKUS TANULMÁNYOK - Kárpátalja társadalma}

\section{Irodalom}

Berghauer, S. (2009): Falusi turizmus. In: Baranyi, B. (szerk.): Kárpátalja. Kárpát-medence régiói 11. Magyar Tudományos Akadémia Regionális Kutatások Központja és Dialóg Campus Kiadó, Pécs - Budapest: 345-346.

Bodnár, L. (2005): Az idegenforgalom hazai és nemzetközi vonatkozásai. Nemzeti Tankönyvkiadó, Budapest: p. 382.

Boros, Sz. (szerk.) (2014): Baross Gábor Terv, Dél-Szlovákia/Felvidék regionális gazdasági fejlesztési terve. Szlovákiai Magyar Közgazdász Társaság, Győr: 155 p.

Chobotova, V. - Kluvankova-Oravska, T. (2006): Rural tourism and resilience of regions. Part of Work package 2. Learning for Social-Ecological Resilience and Diffusion of Innovations. Case study analysis - Slovakia Final report. Institute for Forecasting, Slovak Academy of Sciences, Bratislava: 54. p.

Clarke, J. - Denman, R. - Hickman, G. - Slovak, J. (2001): Rural tourism in Roznava Okres: a Slovak case study. Tourism Management, Elsevier: 193-202.

Egán Ede-Terv, a kárpátaljai magyarság gazdaságfejlesztési stratégiai terve (2014). URL 1, 2016. http://kmksz.com.ua/regi/images/Egan_Ede-terv.pdf Utolsó letöltés: 2016.05.04.

Habán, M. - Macák, M. - Otepka, P. (2012): Rural tourism and agro-tourism in Slovakia. ROCZNIKI EKONOMII ROLNICTWA I ROZWOJU OBSZARÓW WIEJSKICH, T. 99, z. 3: 34-40.

Horváth, Gy. (szerk.) (2004): Dél-Szlovákia. Kárpát-medence régiói 2. Magyar Tudományos Akadémia Regionális Kutatások Központja és Dialóg Campus Kiadó, Pécs - Budapest: 525 p.

Izsák, T. (2016): A falusi turizmus fejlődésének problémái Kárpátalján, Vári település példáján. In: Berghauer, S. - Dnyisztrjanszkij, M. - Fodor, Gy. - Gönczy, S. - Izsák, T. - Jakab, N. - Molnár, J. - Molnár D, I. - Sass, E. - Papp, G. - Vince, T. (szerk.): Társadalomföldrajzi kihívások és adekvát válaszlehetőségek a XXI. század Kelet-Közép-Európájában. Kálvin Nyomda, Beregszász: 519-524.

Jarábková, J. 2008: Evaluation of service quality in rural accommodation. „Acta Regionalia et Environmentalica", Vol. 5, No. 2: 38-41.

Jarábková, J. 2010: Quality Evaluation of accommodation facilities located in rural areas of Nitra Self-governance Region. „Acta Regionalia et Environmentalica”, 1: 12-17.

Kaffka, K. (szerk.) (1939): Az Utas Könyve (II. kiegészítő füzet). Kárpátalja. Országos Magyar Vendégforgalmi Szövetség, Budapest: 82 p.

Kovács, D. (2003): Falusi és vidéki turizmus értelmezések a nemzetközi irodalomban. In: Kovács, D. (szerk.) A Falusi turizmus hagyományai. Mezőgazda Könyvkiadó, Budapest: 57-69. 


\section{TEMATIKUS TANULMÁNYOK - Kárpátalja társadalma}

Кудла, Н. Є. (2015): Сільський туризм: основи підприємництва та гостинності: навч. посіб. Київ: 152 р.

Lanstyák, I. (2000): A magyar nyelv Szlovákiában. A magyar nyelv a Kárpát-medencében a XX. század végén III. Osiris Kiadó, Kalligram Könyvkiadó, MTA Kisebbségkutató Műhely, Budapest - Pozsony: 368 p. (ISBN:963 379827 2)

Magyar Szállodaszövetség (2004): 45/1998. (VI. 24.) IKIM rendelet. URL 2, 2010. http://www.hah.hu/articles/index.php?first=0\&id=88\&lang=hu\&type_id=6, Utolsó letöltés: 2010.10.28.

Molnár, J. - Molnár, D. I. (2005): Kárpátalja népessége és magyarsága a népszámlálási és népmozgalmi adatok tükrében. Kárpátaljai Magyar Pedagógusszövetség Tankönyv- és Taneszköztanács, PoliPrint Kft., Ungvár: 120. p.

Otepka, P. - Habán, M. (2007): Vidiecky turizmus agroturizmus (Rural tourism and agro-tourism). Nitra, ÚVTIP NOI Bratislava: 117 p.

Sass, E. - Szilágyi, Zs. - Gönczy, S. (2007): Kárpátalja, mint turisztikai desztináció ismertsége és imázsa. Régiók a Kárpát-medencén innen és túl, Nemzetközi tudományos konferencia. Eötvös József Főiskola, Baja: 455-460.

Sass, E. (2012): A kárpátaljai Bereg-vidék falusi turizmusának jellemzése egy empirikus kutatás alapján. Társadalomföldrajzi kihívások a XXI. század Kelet-Közép-Európájában Nemzetközi Földrajzi Konferencia, Beregszász: 261-271.

Szabó, B. (szerk.) (2009): A falusi turizmus helyzete és gazdasági kérdései. Párbeszéd a vidékért. MTA Társadalomkutató Központ, Budapest: p. 250.

Szabó, G. (2000): A vidéki turizmus fejlesztési lehetőségei és módszerei geográfiai megközelítésben hazai példák alapján. PhD disszertáció, PTE TTK Földrajzi Intézet, Pécs: 221 p.

Szilágyi, Zs. - Sass, E. - Gönczy, S. (2006): Kárpátalja, mint turisztikai desztináció Magyarországi turisták körében végzett imázs- és elégedettségvizsgálat. A III. Magyar Földrajzi Konferencia tudományos közleményei. MTA Földrajztudományi Kutatóintézet, Budapest, CD-Rom

Tardos, J. (1996): Meglepő! Magyar Mezőgazdaság, LI., 21.: 9. p. Idézi: Szabó B. (szerk.) (2009): A falusi turizmus helyzete és gazdasági kérdései. Párbeszéd a vidékért. MTA Társadalomkutató Központ, Budapest: p. 250.

Tourism Development Strategy of the Slovak Republic until 2013 approved by the Slovak Government in Resolution No. 632 of 24 August 2005. URL 3, 2016. http://pdc.ceu.hu/archive/ 00002751/01/TourismStrategy.pdf Utolsó letöltés: 2016.06.20.

Закон України „Про сільський зелений туризм”. Проект. 2004. URL 4, 2016. http://icp.org.ua/ukr/zakon/akts/2005/08/18/zakon_ukraini_pro_si_206.html Utolsó letöltés: 2016.06.21. 
www. metszetek.unideb.hu

\section{TEMATIKUS TANULMÁNYOK - Kárpátalja társadalma}

Zbierka zákonov č. 277/2008 URL 5, 2016. http://www.ciernybalog.sk/download_ file_f.php?id=45422 Utolsó letöltés: 2016.01.25.

URL 6 (2009) www.karpatinfo.net Utolsó letöltés: 2009.04.12.

URL 7 (2015): http://www.travelguide.sk Utolsó letöltés: 2015.11.25.

URL 8 (2017): A (cseh)szlovákiai magyarok lexikona Csehszlovákia megalakulásától napjainkig. Demográfiai változások. http://adatbank.sk/lexikon/demografiai-valtozasok/ Utolsó letöltés: 2017.11.18.

URL 9 (2018) http://photo.ukrinform.ua/ukr/current/photo.php?id=60544 Utolsó letöltés: 2018.01.18.

URL 10 (2018) http://www.csi.org.ua/20-rokiv-ukrayinskomu-silskomu-zelenomuturyzmu-ta-yiyi-zasnovnyku-go-spilka-spryyannya-rozvytku-silskogo-zelenogo-turyzmu-v-ukrayini/ Utolsó letöltés: 2018.01.18. 